\title{
Characterization of Staphylococcus Aureus of Animal Origin in Nosocomial Infection
}

*Hamza, I.E.; **Marssel, F.G.; ***Mai, W.E.

* Department of Bacteriology, Immunology, Mycology - Faculty of

Veterinary Medicine,

Suez Canal University.

** Department of Food Hygiene, Animal Health Research Institute, Port

Said Branch.

*** Department of Infection Prevention and Healthcare Quality, Port Said Military Hospital.

\begin{abstract}
This study discussed the prevalence of $S$. aureus in some hospitals in Port-Said governorate and the possibility impact of the $S$. aureus isolates from foods of animal origin on nosocomial infections by genetic relatedness between isolates from foods and infected patients.

The bacteriological examination of 355 samples reveals of $S$. aureus in 28 from 255 total samples taken from hospitals kitchens with percentage $11 \%$ and $48 \mathrm{~S}$. aureus isolates from 100 swabs of infected patients with percentage $48 \%$, the antibiotic sensitivity test of most isolates revealed multidrug resistant $S$. aureus strains.

Used random amplified polymorphic DNA (RAPD) patterns to determine genetic relatedness among $S$. aureus isolates that revealed genetic relatedness among the isolates and give indication about the possibility to impact of $S$. aureus isolates from foods of animal origin in human infections.
\end{abstract}

\section{Introduction}

Staphylococcus aureus is Grampositive, coagulase-positive cocci of the family Staphylococcaceae, considering an important cause for both human and animal diseases, such as arthritis, mastitis, and urinary tract infection in animals, while in human pneumonia, food poisoning, and nosocomial infections (John, 2003).

Antimicrobial abuse in animal husbandry and other agricultural activities leads to increase antimicrobial resistant bacteria in both animals and human that transported through contact directly with living animals or indirectly by contact or ingestion of food products of animal origin that also can transfer their resistance genes to commensal flora in intestinal tract. (Kluytmans, 2009).

The present study was carried out to investigate the:

1. Characterization

of

Staphylococcus aureus of animal origin in nosocomial infection. 
a. Isolation of Staphylococcus aureus from different samples in hospitals.

b. Biochemical identification of Staphylococcus isolates.

c. Antibiotic sensitivity of Staphylococcus isolates.

d. PCR detection of Staphylococcus aureus.

2. Determined genetic relatedness among the isolates from foods of animal origins and patients by Random amplified polymorphic DNA (RAPD).

\section{Materials and Methods Samples:}

A total of three hundred and fifty five (355) random samples from the foods of animal origin \&swabs from the surfaces where the food were prepared and lesions swabs of hospital acquired infected patients were collected from some hospitals in Port-Said governorate, two hundred and fifty five samples were collected from the hospitals kitchens where 52 swabs were collected from preparing raw meat and chickens surfaces \& utensils, 50 samples from processed milk products as cheese, yoghurt, butter and powdered milk, 55 samples from raw meat, 45 samples from raw chicken and 53 samples from raw milk, in addition to 100 swabs taken from lesions of hospital acquired infected patients including 50 swabs from septic burned wounds, 25 from surgical sites infection and 25 from draining pus of peripheral venous catheters (cannula) associated abscess, the samples were collected aseptically in polyethylene bags and transported to the laboratory in an isothermal box for subsequent analysis and swabs were placed in peptone saline and transported in a cool box with ice packs.

Bacteriological isolation and identification of Staphylococcus aureus:

According to Quinn et al. (2002) and Koneman et al. (1996); samples were cultured onto pepton water for $24 \mathrm{~h}$ at $37^{\circ} \mathrm{C}$ and then a loopful was taken and cultured onto nutrient agar, blood agar, mannitol salt agar and Baird parker medium. All inoculated plates were incubated at $37^{\circ} \mathrm{C}$ for $24-48 \mathrm{~h}$, suspected colonies of $S$. aureus were examined morphologically, biochemically according to $(\boldsymbol{F D A}$, 2001) and microscopically according to (Ryan and Ray, 2004). Antimicrobial sensitivity test for Staphylococcus aureus:

Disc diffusion test was done according to (Finegold and Martin, 1982) for detection of sensitivity degree of $S$. aureus isolates against 14 different antimicrobial discs (Ampicillin, Methicillin, Cephalexin, Cefaclor, Imipenem, Vancomycin, Bacitracin, Amikacin, Erythromycin, Clindamycin, Chloramphenicol, Ciprofloxacin, Norfloxacin and Trimethoprim + Sulphamethoxazole), degree of sensitivity was determined by measuring the clear zone around 
each disc and interpreted according to (Oxoid, 1982).

Molecular Identification of Isolates:

Samples used for PCR assay:

Sent 17 isolates from foods of animal origin and 19 isolates from patients in the wards that was highly positive reaction for tube coagulase test for PCR assay, missed one sample from animal origin through the transportation, to be the final number of the samples that subjected to PCR assay was 16 isolates from foods of animal origin with total 35 samples.

Oligonucleotide primers used in PCR and RAPD:

Detection of clumping factor in isolates by clfA gene and Methicillin-resistant isolates by mecA gene by means of PCR, in addition to detection RAPD patterns by two arbitrary oligonucleotide primers M13 and $\mathrm{H} 12$ of the isolates.

They have specific sequence and amplify specific products as shown in Table (1).

Table (1): Oligonucleotide primers encoding for PCR

\begin{tabular}{|c|c|c|c|c|}
\hline Target gene & Primer & $\begin{array}{c}\text { Primer seauence } \\
\qquad\left(5^{\prime}-3^{\prime}\right)\end{array}$ & $\begin{array}{c}\text { Length Of amplified } \\
\text { product (bp) }\end{array}$ & Reference \\
\hline \multirow{2}{*}{$m e c \mathrm{~A}$} & $m e c \mathrm{~A}-1$ & $\begin{array}{c}\text { GTA GAA ATG ACT GAA CGT CCG } \\
\text { ATAA }\end{array}$ & \multirow{2}{*}{$310 \mathrm{bp}$} & \multirow{2}{*}{ McClure et al., 2006} \\
\hline & $m e c \mathrm{~A}-2$ & $\begin{array}{c}\text { CCA ATT CCA CAT TGT TTC GGT } \\
\text { CTAA }\end{array}$ & & \\
\hline \multirow{2}{*}{ clf $\mathbf{A}$} & clfA-F & GCAAAATCCAGCACAACAGGAAACGA & \multirow{2}{*}{638 bp } & \multirow{2}{*}{ Mason et al., 2001} \\
\hline & clf $\mathrm{A}-\mathbf{R}$ & CTTGATCTCCAGCCATAATTGGTGG & & \\
\hline & M13 & GAGGGTGGCGGTTCT & Multiple bands & \multirow{2}{*}{ John, 2003} \\
\hline & H12 & ACGCGCATGT & Multiple bands & \\
\hline
\end{tabular}

2.4.3. Cycling conditions of the primers during cPCR:

Table (2): Temperature and time conditions of the primers during PCR

\begin{tabular}{|c|c|c|c|c|c|c|}
\hline Gene & $\begin{array}{c}\text { Primary } \\
\text { denaturation }\end{array}$ & $\begin{array}{c}\text { Secondary } \\
\text { denaturation }\end{array}$ & Annealing & Extension & $\begin{array}{l}\text { No. of } \\
\text { cycles }\end{array}$ & $\begin{array}{c}\text { Final } \\
\text { extension }\end{array}$ \\
\hline mecA & $\begin{array}{l}94^{\circ} \mathrm{C} \\
5 \mathrm{~min} .\end{array}$ & $\begin{array}{l}94^{\circ} \mathrm{C} \\
30 \mathrm{sec} .\end{array}$ & $\begin{array}{c}50^{\circ} \mathrm{C} \\
45 \mathrm{sec} .\end{array}$ & $\begin{array}{c}72^{\circ} \mathrm{C} \\
45 \mathrm{sec}\end{array}$ & 35 & $\begin{array}{c}72^{\circ} \mathrm{C} \\
10 \mathrm{~min} .\end{array}$ \\
\hline clfA & $\begin{array}{l}94^{\circ} \mathrm{C} \\
5 \mathrm{~min} .\end{array}$ & $\begin{array}{c}94^{\circ} \mathrm{C} \\
30 \mathrm{sec} .\end{array}$ & $\begin{array}{l}55^{\circ} \mathrm{C} \\
1 \mathrm{~min} .\end{array}$ & $\begin{array}{l}72^{\circ} \mathrm{C} \\
1 \mathrm{~min} .\end{array}$ & 35 & $\begin{array}{c}72^{\circ} \mathrm{C} \\
10 \mathrm{~min} .\end{array}$ \\
\hline $\begin{array}{l}\text { H12 and } \\
\text { M13 }\end{array}$ & $\begin{array}{r}94^{\circ} \mathrm{C} \\
5 \mathrm{~min} . \\
\end{array}$ & $\begin{array}{l}94^{\circ} \mathrm{C} \\
1 \mathrm{~min} .\end{array}$ & $\begin{array}{l}35^{\circ} \mathrm{C} \\
1 \mathrm{~min} .\end{array}$ & $\begin{array}{r}72^{\circ} \mathrm{C} \\
2 \mathrm{~min} .\end{array}$ & 35 & $\begin{array}{c}72^{\circ} \mathrm{C} \\
12 \mathrm{~min} .\end{array}$ \\
\hline
\end{tabular}

DNA Molecular weight marker:

Hundred (100) bp DNA markers were used. The ladder was mixed gently by pipetting then $6 \mu$ of the required ladder were directly loaded.
Analysis of Random amplified polymorphic DNA fingerprinting (RAPD) data:

Used GelCompar $\Pi$ software (version 6.6; Applied Maths, Belgium, 2013) for analyzing 
banding patterns that generated from each primer by calculate the different band-based similarity coefficient and the average of experiments for both primers to generate a dendrogram by the unweighted pair group method using arithmetic average clustering.

\section{Results and discussion}

Among 255 specimens from hospitals kitchens examined in this study, 28 contained $S$. aureus with a percentage of $11 \%$. Prevalence of $S$. aureus from raw meat was $21.8 \%$, from raw chicken was $4.4 \%$ and raw milk was $26.4 \%$, while $S$. aureus failed to be detected in the samples from processed milk products as (cheese, yoghurt, butter, and powdered milk) and swabs from preparing raw meat and chickens surfaces and utensils, as shown in table (3).

The detection of $S$. aureus in raw milk and raw meat may be due to unclean worker hands, inferior quality of water supplied for washing utensils and carcasses, unhygienic transportation, bad storage and may be returned to milking process from subclinical mastitic cows and slaughter $S$. aureus positive animals, the present results are in line with the finding of (Normannoa et al., 2007, Boer et al., 2009, Kluytmans, 2009 and Sarah, 2014).

In this study, a total of 100 swabs from human origin were examined bacteriologically to reveal 48 isolates of $S$. aureus with incidence of $48 \%$. The isolates were from septic burned wound with percentage $40 \%$, surgical site infection $40 \%$ and draining pus of peripheral venous catheters (cannula) associated abscess \& cellulites $72 \%$, as shown in table (3), these results were more than the results of (El-Jakee et al., 2008) who investigated bacteriologically to detect the occurrence of $S$. aureus in 50 samples from diseased human and found $14 \mathrm{~S}$. aureus isolates with percentage $28 \%$ but the percentage of $S$. aureus isolates from septic wound was similar to the present results with percentage $45 \%$, The results consider evidence that $S$. aureus responsible for the most health care acquired infection in hospitals.

It was evident from the present work that, there were highly resistance to $\beta$-lactam antibiotics as penicillins group (Ampicillin and methicillin) and cephalosporins group (cephalexin and cefaclor) of $S$. aureus isolates from both human and foods of animal origin, while $58 \%$ from human isolates were resistant to imipenem unlike the isolates from food of animal origin that were highly sensitive to imipenem with percentage $100 \%$.

On other hand, all isolates from foods of animal origin were resistant to vancomycin while $62.5 \%$ only from human isolates were resistant to it. Moreover, resistance of $S$. aureus isolates against chloramphenicol and amikacin was slightly low in foods 
of animal origin isolates with percentage $18 \% \quad \& \quad 39.3 \%$ respectively, while was high in human isolates with percentage $93.7 \%$ \& $83.3 \%$ respectively, as shown in figures $(1 \& 2)$.

The present finding indicate to high prevalence of multidrug resistant $S$. aureus in both foods and patients isolates and what we are very close to dangerous zone where cannot find suitable antibiotics for these organisms that agree with those mentioned by (WHO, 2015) who recorded spread of antibiotic resistant bacteria in countries where antibiotics can be bought without a prescription or haven't standard treatment guidelines and warned from rising of resistance to dangerously high levels where minor injuries can once again kill and without urgent action, we are heading for a post-antibiotic era.

Genetic relatedness among the isolates ranged from $90 \%$ to $100 \%$ classified to 17 patterns according to the similarity values that exceed 95\% in combined $\mathrm{H} 12$ and M13 primers, as shown in figure (3).

These revealed high genetic similarity among some isolates from foods of animal origin such as $2 \mathrm{~A}, 3 \mathrm{~A}, 4 \mathrm{~A}, 5 \mathrm{~A}$ and $6 \mathrm{~A}$ isolates that possessed RAPD pattern type P2 with $96.3 \%$ genetic similarity and $12 \mathrm{~A} \& 11 \mathrm{~A}$ that possessed RAPD pattern type $\mathrm{P} 4$ with $96.8 \%$ genetic similarity in addition to $8 \mathrm{~A}, 9 \mathrm{~A}$ and 10A that possessed RAPD pattern type P5 with $96.5 \%$ genetic similarity. Also, the same in some isolates from infected patients such as $15 \mathrm{H}, 17 \mathrm{H}$ and $19 \mathrm{H}$ that possessed RAPD pattern type P10 with $95.1 \%$ genetic similarity and $9 \mathrm{H} \& 13 \mathrm{H}$ that possessed RAPD pattern type P11 with $95.9 \%$ genetic similarity, in addition to $1 \mathrm{H}$ and $2 \mathrm{H}$ that possessed RAPD pattern type P13 with $95.8 \%$ genetic similarity, moreover $3 \mathrm{H}, 4 \mathrm{H}$ and $7 \mathrm{H}$ that possessed RAPD pattern type P14 with $97.4 \%$ genetic similarity, these results have clear reason that all of these isolates came from the same origin.

While found genetic relatedness among one isolate from raw meat $1 \mathrm{~A}$ and another one from surgical site infection $11 \mathrm{H}$ that possessed RAPD pattern type P1 with $95 \%$ genetic similarity, in addition to genetic relatedness between 13A \& $14 \mathrm{~A} \& 16 \mathrm{~A}$ isolates from raw milk and $12 \mathrm{H}$ isolate from surgical site infection that possessed RAPD pattern type P3 with $95.8 \%$ genetic similarity that indicate possibility to impact of $S$. aureus isolates from foods of animal origin in human infections.

This result agree with (John, 2003) who found identical RAPD patterns between some isolates from food animals and certain isolates from humans that reveals the possibility of transmission the infection from contaminated food product from infected animals to humans, (WHO, 2015) mentioned 1 in 5 resistant infections in humans are caused by germs from food and animals, (CDC, 2013) recorded $22 \%$ of 
antibiotic-resistant illness in humans is in fact linked to food and (Scott, 2010) who mentioned that contaminated food with MRSA is plausible and has role in human infection.

(CDC, 2013 and WHO, 2015) attributed this phenomenon to antibiotics that given to animals, most bacteria are killed but resistant bacteria can survive, multiply and spread through animal products or contaminated foods from environment to people who get sick with resistant infections and lead to mild illness or severe illness and may lead to death.

Table (3): Prevalence of S. aureus that isolated from some hospitals in PortSaid governorate:

\begin{tabular}{|c|c|c|c|c|}
\hline \multirow{2}{*}{ locations } & \multirow{2}{*}{ sources of the samples } & \multirow{2}{*}{$\begin{array}{c}\text { number of } \\
\text { examined } \\
\text { samples }\end{array}$} & \multicolumn{2}{|c|}{ Bacteriological finding } \\
\hline & & & $\begin{array}{l}\text { No. of positive } \\
\text { samples }\end{array}$ & $\%$ \\
\hline \multirow{5}{*}{$\begin{array}{l}\text { From the } \\
\text { kitchens }\end{array}$} & $\begin{array}{l}\text { surfaces and utensils used for raw } \\
\text { meat and chickens }\end{array}$ & 52 & 0 & 0 \\
\hline & $\begin{array}{l}\text { processed milk products (cheese, } \\
\text { yoghurt, butter and powdered milk) }\end{array}$ & 50 & 0 & 0 \\
\hline & raw meat & 55 & 12 & 21.8 \\
\hline & raw chicken & 45 & 2 & 4.4 \\
\hline & raw milk & 53 & 14 & 26.4 \\
\hline & Total & 255 & 28 & 11 \\
\hline \multirow{3}{*}{$\begin{array}{l}\text { From the } \\
\text { wards }\end{array}$} & Septic burned wounds & 50 & 20 & 40 \\
\hline & surgical sites infection & 25 & 10 & 40 \\
\hline & draining pus (abscess \& cellulites) & 25 & 18 & 72 \\
\hline \multicolumn{2}{|r|}{ Total } & 100 & 48 & 48 \\
\hline
\end{tabular}




\section{Resistance \%}

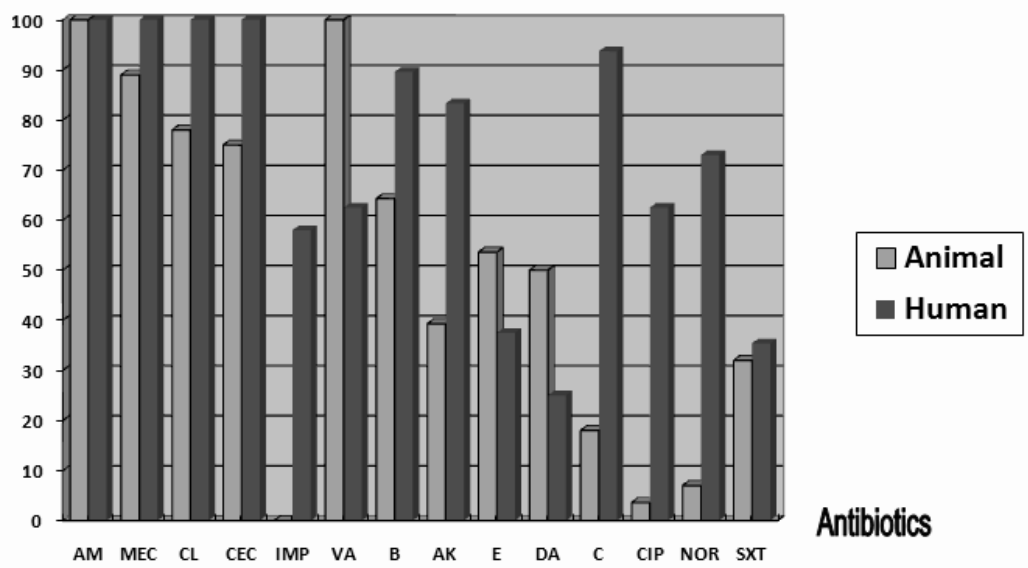

Fig (1): Resistance rate of S. aureus strains isolated from both animal products in kitchens and patients in wards against various antibiotics.

\section{Sensetivity\%}

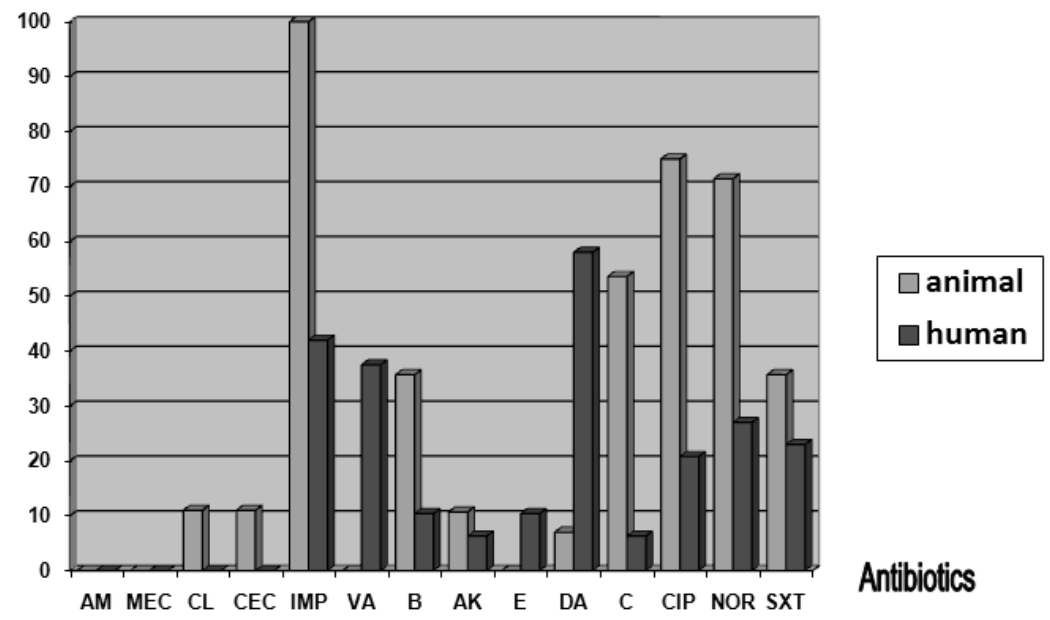

Fig (2): Sensitivity rate of $S$. aureus strains isolated from both animal products in kitchens and patients in wards against various antibiotics. 


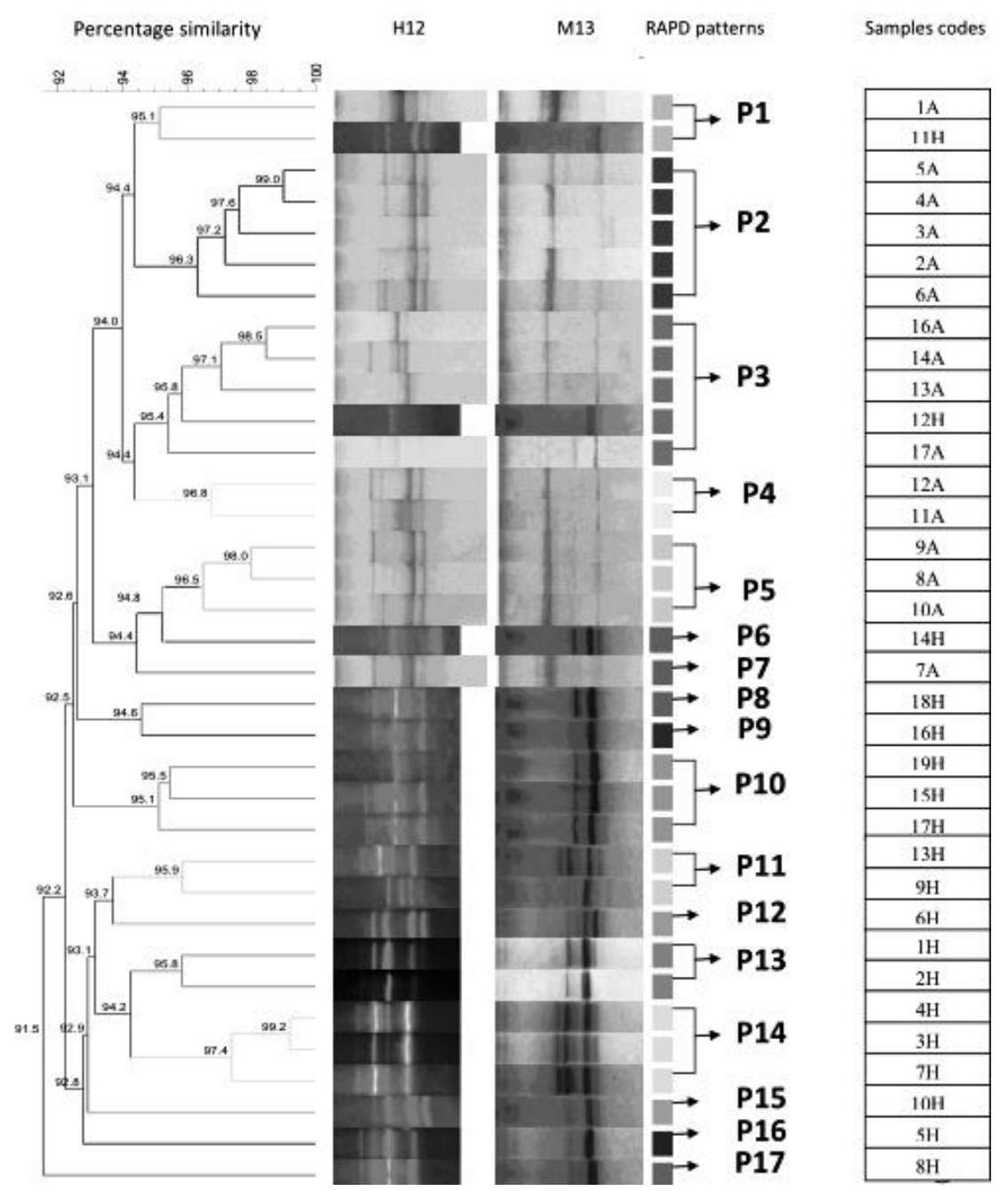

Figure (3): Dendrogram showing the levels of similarity between RAPD patterns of $35 \mathrm{~S}$. aureus isolates based on the combination between M13 \& H12 results.

\section{Conclusion and recommendation}

It can be concluded that high prevalence of multi drug resistant $S$. aureus in both isolates from foods of animal origin and infected patients in addition to transmission S. aureus from contaminated food products of animal origin to humans is very plausible.
It can emphasize on (WHO, 2015) recommendation for global action plan as following:

1. Improve awareness of the impact of antimicrobial resistance.

2. Support research works and antimicrobial resistance surveillances.

3. Activate the infection prevention measures. 
4. Promote the appropriate use of antimicrobial medicines.

5. Apply action plan for countering antimicrobial resistance.

The agricultural sector can help by:

1. Ensure that antibiotics given to animals are only used to treat infectious diseases and under veterinary supervision.

2. Reduce the need for antibiotics by vaccinating animals.

3. Strengthen the good practices during processing of foods that originated from animal.

4. Handling of animals under hygienic condition.

5. Apply international standards that set out by OIE, FAO and WHO.

\section{References}

Boer, E.; Zwartkruis-Nahuis, J.T.; Wit, B.; Huijsdens, X.W.; Neeling, A.J.; Bosch, T.; van, O.R.A; Vila, A. and Heuvelink, A.E. (2009): Prevalence of methicillin-resistant Staphylococcus aureus in meat. Int $\mathbf{J}$ Food Microbiol. Aug 31; 134(12):52-68.

Centers for Disease Control and Prevention (CDC) (2013): Antibiotic Resistant Threats in the United States.

El-Jakee, J.; Nagwa Ata, S.; Bakry, M.; Sahar, A.; Zouelfakar; Elgabry, E. and Gad El-Said, W.A. (2008): Characteristics of Staphylococcus aureusStrains Isolated from Human and Animal Sources. American-Eurasian J. Agric. \& Environ. Sci., 4 (2): 221-229.

Finegold, S. M. and Martin, W. J. (1982): Diagnostic Microbiology. In 6th Ed., C. V. Mosby Co., St. Louis, Toronto, London.

Food and Drug Administration (FDA) (2001): Food Drug Adm., Bact. Analytical manual.Chapter 12 Staphylococcus aureus. Reginald, W. B. and Gayle A. L.

John Hwa Lee (2003): Methicillin (Oxacillin)-Resistant Staphylococcus aureus Strains Isolated from Major Food Animals and Their Potential Transmission to Humans. Appl. Environ. Microbiol. 69(11):64-89.

Kluytmans, J. A. J. W., (2009): Methicillin-resistant Staphylococcus aureus in food products: cause for concern or case for complacency? Clin Microbiol Infect; 16: 11-15.

Koneman, E.W.; Allen, S. D.; Janda, W.M.; Schreckenberger, P. C. and Winn, M.D. (1996): Introduction to Diagnostic Microbiology 6th ed., Lippincott company, Philadelphia, USA.

Mason, W.J.; Blevins, J.S.; Beenken, K.; Wibowo, N.; Ojha, N. and Smeltzer, M.S. (2001): Multiplex PCR Protocol for the Diagnosis of Staphylococcal Infection. Journal of Clinical Microbiology, Vol. 39, No. 9, p. 3332-3338.

McClure, J-A; Conly, JM; Lau, V; Elsayed, S; Louie, T; Hutchins, W and Zhang, K. (2006): Novel multiplex PCR assay for detection of the staphylococcal virulence marker Panton-Valentine leukocidin genes and simultaneous discrimination of methicillin-susceptible from -resistant staphylococci. J Clin Microbiol 44: 1141-2114.

Normannoa, G.; Correntea, M.; La Salandrab, G.; Dambrosioa, 
A.; Quagliaa,

A.; Grecoa,

A.L.; Virgilioc

G.V.

(2007):

N.C.; Parisib,

G.; Bellaciccoa,

resistant Staphylococcus

aureus (MRSA) in foods of animal origin product in Italy. J. Food Microbiology Volume 117, Issue 2, 30 June, Pages 219-222.

Oxoid manual (1982): The Oxoid manual culture media, ingredients and other Laboratory service. 5th edition, oxoid limited, Hampshire, R.G.240 P.W., England.

Quinn, P.J.; Markey, B.K.; Carter, M.E.; Donnelly, W.J.C.; Leonard, F.C. and Maguire, D. (2002): Veterinary Microbiology and
Microbial diseses.1 published Blackwell science 1st ed.

Ryan, K.J. and Ray, C.G. (2004): Sherris Medical Microbiology (4th ed.). McGraw Hill. ISBN 0-83858529-9.

Sarah M. Abbas (2014): Molecular characterization of Staphylococcus aureus isolated from meat, milk and their products. M.V.Sc., Vet. Med., Suez Canal University.

Scott Weese, J. (2010): MethicillinResistant Staphylococcus aureus in Animals. ILAR Journal, Volume 51, Number 3.

World health organization (WHO) (2015): World Health Assembly addresses antimicrobial resistance, immunization gaps and malnutrition.

$$
\begin{aligned}
& \text { توصيف المكور العنقودي الذهبي ذو المصدر الحيواني في عدوى المستثفيات }
\end{aligned}
$$

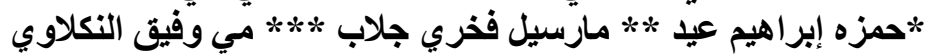

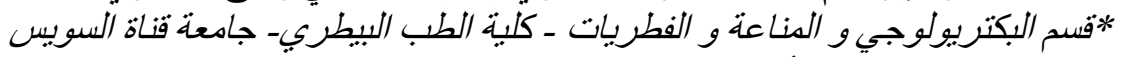

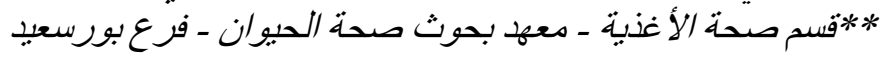

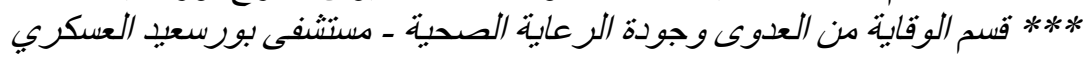

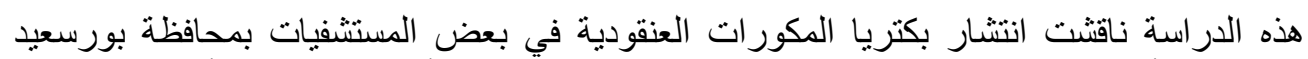

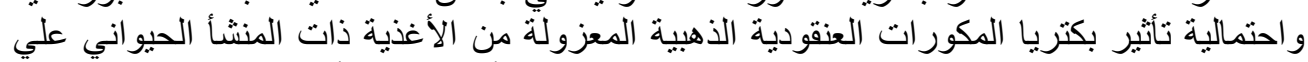

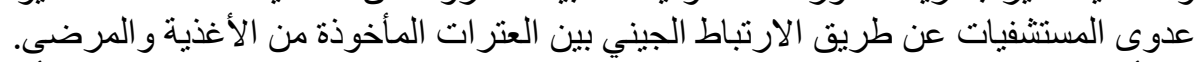

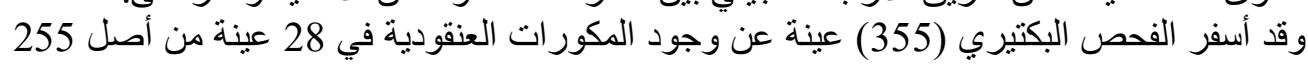
عينة تم عزلها من مطابخ المستشفيات بنسبة 11\% و و 48 عترة من المكور ات العنقة العنودية من إجمالي

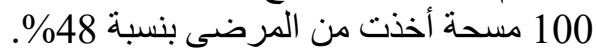

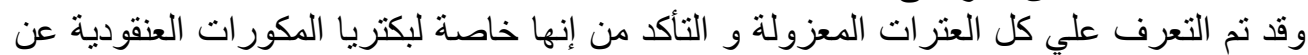

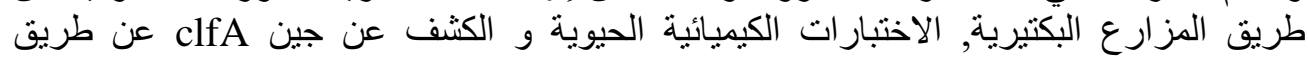

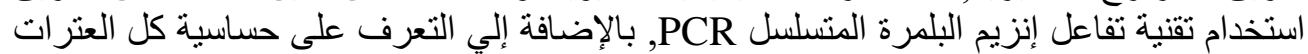

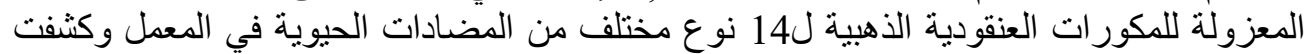
النتائج عن مقاومة المكور التفات العنقودية للعديد منها.

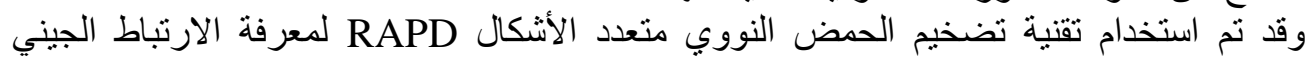

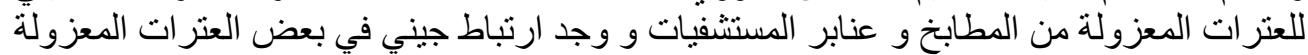

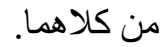
أسفرت النتائج عن احتمالية انتقال العدوى إلى الإنسان عن طريق أطعمة من أصل حيو اني ملوثة

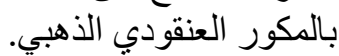

